\title{
METODE BERCERITA UNTUK SISWA SD
}

\author{
Novita Tabelessy \\ Pendidikan Bahasa dan Sastra Indonesia, FKIP Universitas Pattimura; \\ noviariel.NF@gmail.com
}

\begin{abstract}
Abstrak: Bercerita adalah menuturkan sesuatu yang mengisahkan tentang perbuatan atau suatu kejadian dan disampaikan secara lisan dengan tujuan membagikan pengalaman dan pengetahuan kepada orang lain. Kegiatan bercerita atau bertutur bagi semua kalangan (siapa saja) dapat dilakukan dengan baik jika dilakukan dengan metode yang tepat, sehingga apa yang hendak disampaikan kepada orang lain dapat diterima dan dimaknai dengan baik juga. Pengabdian yang dilakukan di SD Inpres Yafila merupakan kegiatan dalam bentuk memberikan materi yang berhubungan dengan metode bercerita siswa SD, dan kegiatan tersebut melibatkan siswa SD kelas IV dan guru mata pelajaran Bahasa Indoensia. Tujuan pelaksanaan pengabdian yaitu untuk memberikan pengetahuan tentang metode bercerita bagi siswa SD kelas IV. Metode yang dipakai dalam kegiatan pengabdian kepada masyarakat di SD Inpres Yafila yaitu metode dengan bentuk interaktif; hal yang terkait dengan komunikasi dua arah dan saling melakukan aksi, saling aktif dan saling berhubungan serta mempunyai hubungan timbal balik antara satu dengan yang lainnya (dalam hal ini pemateri, guru dan siswa kelas IV SD). Kegiatan pengabdian yang dilakukan banyak memberikan manfaat dan tujaun bercerita bagi siswa kelas $I V$, sehingga dapat membantu mereka dalam menyiapkan diri untuk megikuti lomba-lomba bercerita atau beruttur antarsekolah, dan materi yang diberikan juga bermanfaat tentunya bagi guru, khususnya guru mata pelajaran Bahasa Indoensia. Secara umum ada dua bentuk metode bercerita yang dapat digunakan siswa untuk bercerita di depan umum, yaitu bercerita tanpa alat peraga dan bercerita dengan alat peraga.
\end{abstract}

Kata Kunci: Metode bercerita, siswa, guru, interaktif.

Abstract: Storytelling is telling something that tells about an act or event and is conveyed verbally with the aim of sharing experiences and knowledge with others. Storytelling activities can be done well in any group if it uses the right method, so that what is going to be conveyed to others can be accepted and interpreted properly. The dedication carried out at Yafila Inpres Elementary School is an activity in the form of giving material related to elementary students' story telling methods, involving fourth grade elementary school students. The method used in community service activities at the Yafila Inpres Elementary School is an interactive method; matters related to two-way communication and taking action, being mutually active and interconnected, also having a reciprocal relationship between one another (in this case the speaker, teacher and grade IV SD students). The service activities carried out provide many benefits and purposes for storytelling for fourth grade students, in order to help them prepare themselves for participating in inter-school storytelling competitions. The material provided is also beneficial for teachers, especially Indonesian language teachers. In general, there are two forms of storytelling methods, namely telling stories without props and telling stories with props. Keywords: Storytelling method, students, teachers, interactive. 


\section{PENDAHULUAN}

Berbicara adalah aspek kedua dalam keterampilan berbahasa, setelah keterampilan menyimak, sebagai langkah awal menuju terampil berbicara. Berbicara adalah salah satu keterampilan berbahasa yang berkembang pada kehidupan manusia sejak masih anak-anak. Berbicara merupakan salah satu keterampilan berbahasa yang bersifat aktif produktif, karena tujuannya adalah menyampaikan pesan secara lisan dan langsung kepada orang lain. Kegiatan berbicara juga tidak terlepas dari keterampilan berbahasa lainnya, yaitu menyimak, membaca, dan menulis. Keempat keterampilan berbahasa tersebut saling berkaitan dan terintegrasi.

Salah satu contoh dari kegiatan berbicara yaitu bercerita atau bertutur. Bercerita adalah menuturkan sesuatu yang mengisahkan tentang perbuatan atau suatu kejadian dan disampaikan secara lisan dengan tujuan membagikan pengalaman dan pengetahuan kepada orang lain. Pendapat lain juga mengatakan bercerita adalah upaya untuk mengembangkan potensi kemampuan berbahasa anak melalui pendengaran dan kemudian menuturkannya kembali dengan tujuan melatih keterampilan anak dalam bercakap-cakap untuk menyampaikan ide dalam bentuk lisan. Dengan kata lain bercerita adalah menuturkan sesuatu yang mengisahkan tentang perbuatan atau suatu kejadian secara lisan dalam upaya untuk mengembangkan potensi kemampuan berbahasa.

Kegiatan bercerita atau bertutur bagi semua kalangan (siapa saja) dapat dilakukan dengan baik sesuai aturan-aturan yang ada. Aturan-aturan yang dimaksudkan yaitu bagaimana metode bercerita yang dipilih atau dipakai dapat diterapkan dengan baik. Ada berbagai metode yang dapat dilakukan ketika seseorang akan bercerita atau bertutur di depan umum. Siswa SD ketika ditugaskan untuk bercerita atau mengikuti lomba bercerita atau bertutur, juga harus memperhatikan teknik dalam bercerita dan harus tepat memilih metode apa yang akan digunakan.

Pengabdian yang dilakukan di SD Inpres Yafila merupakan kegiatan memberikan materi tentang metode bercerita untuk siswa SD. Kegiatan tersebut melibatkan siswa SD kelas IV yang berjumlah 25 siswa dan juga guru. Banyak dari mereka yang belum memahami dengan benar apa yang dimaksudkan dengan bercerita. Banyak yang belum pernah diberi kesempatan dari pihak sekolah untuk mengikuti lomba bercerita/bertutur. Banyak juga yang tidak tahu teknik bercerita maupun metode bercerita ketika ditugaskan untuk bercerita. Contoh paling sederhana ketika siswa diberi kesempatan untuk bercerita pengalaman sesehari saja, mereka tidak bisa melakukannya dengan baik. Mengapa demikian ? karena mereka minim informasi atau minim pengetahuan tentang metode bercerita.

Kegiatan yang dilakukan di kelas IV berdampak positif bagi siswa-siswanya, karena pemateri dapat memberikan materi tentang metode bercerita bagi mereka, selain itu pemateri juga memberi kesempatan bagi mereka untuk bercerita apa saja yang menjadi pengalaman mereka, dan yang terjadi siswa-siswa tersebut berlomba-lomba ingin bercerita tentang kisah mereka. Hal ini berdampak baik karena dapat membantu guru bagaimana siswa-siswanya dapat dipersiapkan untuk mengikuti lomba-lomba bercerita/bertutur.

\section{METODE}

Kegiatan pengabdian ini dilakukan di dalam kelas khusus untuk siswa SD kelas IV dan kegiatan berlangsung dari jam $09.00-12.00$ WIT. Metode yang digunakan dalam kegiatan 
pengabdian kepada masyarakat di SD Inpress Yafila khususnya kepada siswa kelas IV adalah dalam bentuk interakrif, dalam artian hal yang terkait dengan komunikasi dua arah dan saling melakukan aksi, saling aktif dan saling berhubungan serta mempunyai hubungan timbal balik antara satu dengan yang lainnya (dalam hal ini pemateri, guru dan siswa).

Selain memberikan materi tentang metode bercerita, pemateri juga memberikan latihan (melatih) siswa untuk bercerita di depan kelas dan didampingi guru. Selain bentuk interaktif yang dipakai, diskusi juga dipakai dalam kegiatan tersebut, banyak hal yang didiskusi antara pemateri dan guru menyangkut hal-hal teknis yang akan dipersiapkan untuk siswa dalam mengikuti lomba bercerita antarsekololah.

\section{PEMBAHASAN}

\section{a. Pengertian Bercerita}

Menurut Nurgiyantoro (2001:289) Bercerita merupakan salah satu bentuk tugas kemampuan berbicara yang bertujuan untuk mengungkapkan kemampuan berbicara yang bersifat pragmatis. Ada dua unsur penting yang harus dikuasai siswa dalam bercerita yaitu linguistik dan unsur apa yang diceritakan. Ketepatan ucapan, tata bahasa, kosakata, kefasihan dan kelancaran, menggambarkan bahwa siswa memiliki kemampuan berbicara yang baik. Selain pendapat di atas, Tarigan (2008:35) berpendapat bahwa bercerita merupakan salah satu keterampilan berbicara yang bertujuan untuk memberikan informasi kepada orang lain. Dikatakan demikian karena berbicara termasuk dalam situasi informatif yang ingin membuat pengertian-pengertian atau makna-makna menjadi jelas. Dengan bercerita seseorang dapat menyampaikan berbagai macam cerita, ungkapan berbagai perasaan sesuai dengan apa yang dialami, dirasakan, dilihat, dibaca dan ungkapan kemauan dan keinginan membagikan pengalaman yang diperolehnya.

Bercerita adalah suatu kegiatan yang dilakukan seseorang secara lisan kepada orang lain dengan alat tentang apa yang harus disampaikan dalam bentuk pesan, informasi, atau hanya sebuah dongeng yang dikemas dalam bentuk cerita yang dapat didengarkan dengan rasa menyenangkan.

Dalam kegiatan bercerita anak dibimbing mengembangkan kemampuan untuk mendengarkan cerita. Melalui metode bercerita anak akan dapat mengembangkan kemampuan bahasanya, dapat mengulang bahasa yang didengarnya dengan bahasa yang sederhana, sehingga metode bercerita berpengaruh terhadap kemampuan berbicara anak.

\section{b. Manfaat dan Tujuan Bercerita}

- Manfaat bercerita

Bercerita memiliki banyak manfaat bagi siswa, sebenarnya tak hanya bagi anak-anak tetapi juga bagi orang yang mendongengkannya. Menurut Hibana "Dalam Kusmiadi, 2008", manfaat dari kegiatan mendongeng ini antara lain ialah:

1. Mengembangkan fantasi, empati dan berbagai jenis perasaan lain.

2. Menumbuhkan minat baca.

3. Membangun kedekatan dan keharmonisan.

4. Media pembelajaran. 
Metode bercerita bermanfaat bagi perkembangan anak. Menurut Madyawati (2016), terdapat beberapa manfaat metode bercerita yaitu sebagai berikut:

1. Membantu pembentukan pribadi dan moral anak. Cerita sangat efektif membantu pribadi dan moral anak. Melalui cerita, anak dapat memahami nilai baik dan buruk yang berlaku di masyarakat.

2. Menyalurkan kebutuhan imajinasi dan fantasi. Cerita dapat dijadikan sebagai media menyalurkan imajinasi dan fantasi anak. Pada saat menyimak cerita, imajinasi yang dibangun anak saat menyimak cerita memberikan pengaruh positif terhadap kemampuan anak dalam menyelesaikan masalah secara kreatif.

3. Memacu kemampuan verbal anak. Cerita dapat memacu kecerdasan linguistik anak. Cerita mendorong anak bukan saja senang menyimak cerita tetapi juga senang bercerita atau berbicara. Anak belajar tata cara berdialog dan bernarasi.

4. Kegiatan bercerita memberikan sejumlah pengetahuan social, nilai-nilai moral dan keagamaan. Bercerita memberikan nilai-nilai sosial pada anak, seperti patuh pada perintah orangtua, mengalah pada adik, dan selalu bersikap jujur. Selain pengetahuan sosial kegiatan bercerita merupakan alat pendidikan budi pekerti yang paling mudah dicerna anak di samping teladan yang dilihat anak tiap hari.

5. Kegiatan bercerita memberikan pengalaman belajar untuk melatih pendengarannya. Dalam kegiatan bercerita anak akan menyampaikan berbagai macam ungkapan, berbagai perasaan sesuai dengan apa yang dialami, dirasakan, dilihat, didengar. Dengan melatih pendengarannya akan menambah kosa kata bagi anak.

6. Memberikan pengalaman belajar dengan menggunakan metode bercerita memungkinkan anak mengembangkan kemampuan kognitif, afektif, dan psikomotor.

7. Memberikan pengalaman belajar yang unik dan menarik, serta dapat mengatakan perasaan, membangkitkan semangat dan menimbulkan keasyikan tersendiri. Kegiatan bercerita memberikan daya tarik bagi anak sehingga akan menimbulkan semangat dan keasyikan dalam bercerita.

- Tujuan bercerita

Bertujuan untuk memberi pengalaman pelajaran agar anak memperoleh penguasaan isi cerita yang disampaikan dengan baik, melalui bercerita anak juga menyerap pesan-pesan yang dituturkan Penuturan cerita yang sarat informasi atau nilai-nilai itu dihayati anak dan diterapkan dalam kehidupan sehari-hari.

Metode bercerita bertujuan untuk menghibur, melatih anak berkomunikasi dengan baik, memahami pesan dari cerita dan mampu mengungkapkan ide cerita serta menambah wawasan dan pengetahuan bahasa secara luas. Menurut Mudini dan Purba (2009), tujuan metode bercerita adalah sebagai berikut:

1. Mendorong atau menstimulasi. Maksud dari mendorong atau menstimulasi yaitu apabila pembicara berusaha memberi semangat dan gairah hidup kepada pendengar. Reaksi yang diharapkan adalah menimbulkan inspirasi atau membangkitkan emosi para pendengar.

2. Meyakinkan. Maksud dari meyakinkan yaitu apabila pembicara berusaha mempengaruhi keyakinan, pendapat atau sikap para pendengar. Alat yang paling penting dalam meyakinkan adalah argumentasi. Untuk itu, diperlukan bukti, fakta, dan contoh konkret yang dapat memperkuat argumentasi untuk meyakinkan pendengar. 
3. Menggerakkan. Maksud dari menggerakkan apabila pembicara menghendaki adanya tindakan atau perbuatan dari para pendengar. Misalnya, mengadakan aksi sosial. Dasar dari tindakan atau perbuatan itu adalah keyakinan yang mendalam atau terbakarnya emosi.

4. Menginformasikan. Maksud dari menginformasikan yaitu apabila pembicara ingin memberi informasi tentang sesuatu agar para pendengar dapat mengerti dan memahaminya. Misalnya guru menyampaikan materi di kelas,

5. Menghibur. Maksud dari menghibur yaitu apabila pembicara bermaksud menggembirakan atau menyenangkan para pendengarnya. Pembicaraan seperti ini biasanya dilakukan dalam suatu resepsi, ulang tahun, pesta, atau pertemuan gembira lainnya.

\section{c. Bentuk Metode Bercerita}

Menurut Dhien (2009), metode bercerita dibagi menjadi dua bentuk, yaitu:

a. Bercerita tanpa alat peraga

Bercerita tanpa alat peraga yaitu kegiatan bercerita yang dilakukan oleh guru atau orang tua tanpa menggunakan media atau alat peraga yang diperlihatkan pada anak. Bercerita tanpa alat peraga adalah bentuk cerita yang mengandalkan kemampuan pencerita dengan menggunakan mimik (ekspresi muka), pantomim (gerak tubuh), dan vokal pencerita sehingga yang mendengarkan dapat menghidupkan kembali dalam fantasi dan imajinasinya. Guru harus memperhatikan ekspresi wajah, gerak-gerik tubuh, dan suara guru harus dapat membantu fantasi anak untuk mengkhayalkan hal-hal yang diceritakan guru.

b. Bercerita dengan alat peraga

Metode bercerita dengan alat peraga yaitu metode bercerita menggunakan media atau alat pendukung untuk memperjelas penuturan cerita yang akan disampaikan. Bercerita dengan menggunakan alat peraga adalah bentuk bercerita yang menggunakan alat peraga bantu untuk menghidupkan cerita. Fungsi alat peraga ini untuk menghidupkan fantasi dan imajinasi sehingga terarah sesuai dengan yang diharapkan si pencerita. Bentuk bercerita dengan alat peraga terbagi menjadi dua, yaitu alat peraga langsung dan alat peraga tidak langsung.

Alat peraga langsung, yaitu menggunakan benda asli atau benda sebenarnya (misalnya: kelinci, kembang, piring) agar anak dapat memahami isi cerita dan dapat melihat langsung ciri-ciri serta kegunaan dari alat tersebut. Alat peraga tidak langsung, yaitu menggunakan benda-benda yang bukan alat sebenarnya. Bercerita dengan alat peraga tak langsung dapat berupa:

a. Bercerita dengan benda-benda tiruan. Guru menggunakan benda-benda tiruan sebagai alat peraga (misalnya: binatang tiruan, buah-buahan tiruan, sayuran tiruan). Benda-benda tiruan tersebut hendaknya mempunyai proporsi bentuk dan warna yang sesuai dengan aslinya.

b. Bercerita dengan menggunakan gambar-gambar. Guru menggunakan gambar sebagai alat peraga dapat berupa gambar lepas, gambar dalam buku atau gambar seri yang terdiri dari 2 sampai 6 gambar yang melukiskan jalannya cerita.

c. Bercerita dengan menggunakan papan flanel. Guru menggunakan papan flanel untuk menempelkan potongan-potongan gambar yang akan disajikan dalam suatu cerita. 
d. Membacakan cerita. Guru menggunakan buku cerita dengan tujuan agar minat anak terhadap buku semakin bertambah.

e. Sandiwara boneka. Guru menggunakan berbagai macam boneka yang akan dipentaskan dalam suatu cerita.

\section{d. Langkah-langkah Metode Bercerita}

Menurut Tarigan (2008), terdapat beberapa langkah yang harus dilakukan dalam pelaksanaan metode bercerita yaitu sebagai berikut:

1. Menentukan topik cerita yang menarik

Topik merupakan pokok pikiran atau pokok pembicaraan. Pokok pikiran dalam cerita harus menarik agar pendengar tertarik dan senang dalam mendengarkan cerita.

2. Menyusun kerangka cerita dengan mengumpulkan bahan-bahan

Kerangka cerita merupakan rencana penulisan yang memuat garis-garis besar dari suatu cerita. Dalam menyusun kerangka cerita, harus mengumpulkan bahan-bahan seperti dari buku, majalah, koran, makalah dan sebagainya, untuk memudahkan dalam merangkai suatu cerita. Contoh kerangka cerita dengan topik persahabatan.

3. Mengembangkan kerangka cerita

Kerangka cerita yang sudah dibuat kemudian dikembangkan sesuai dengan pokokpokok cerita.

4. Menyusun teks cerita

Penyusunan teks cerita dilakukan dengan menggabungkan poin-poin dari kerangka cerita yang telah dikembangkan dengan memperhatikan keterkaitan antarpoin sehingga menjadi sebuah teks cerita yang baik.

\section{KESIMPULAN}

Bercerita adalah menuturkan sesuatu yang mengisahkan tentang perbuatan atau suatu kejadian dan disampaikan secara lisan dengan tujuan membagikan pengalaman dan pengetahuan kepada orang lain. Kegiatan pengabdian yang dilakukan banyak memberikan manfaat dan tujaun bercerita bagi siswa kelas IV SD Inpres Yafila Maluku Tengah, sehingga dapat membantu mereka dalam menyiapkan diri untuk megikuti lombalomba bercerita atau beruttur antarsekolah,

Metode yang digunakan dalam kegiatan pengabdian kepada masyarakat di SD Inpress Yafila khususnya kepada siswa kelas IV adalah dalam bentuk interakrif dan diskusi yang melibatkan pemateri, guru dan siswa.

Menurut Dhien (2009), metode bercerita dibagi menjadi dua bentuk, yaitu: (1) metode bercerita tanpa alat peraga adalah bentuk cerita yang mengandalkan kemampuan pencerita dengan menggunakan mimik (ekspresi muka), pantomim (gerak tubuh), dan vokal pencerita sehingga yang mendengarkan dapat menghidupkan kembali dalam fantasi dan imajinasinya. (2) metode bercerita dengan alat peraga yaitu metode bercerita menggunakan media atau alat pendukung untuk memperjelas penuturan cerita yang akan disampaikan. 


\section{REFERENSI}

Arsjad, Maidar G. 1993. Pembinaan Kemampuan Berbicara Bahasa Indonesia. Jakarta: Erlangga.

Dhien, Nurbiana, dkk. 2009. Materi Pokok Metode Pengembangan Bahasa. Jakarta: Universitas Terbuka.

Faizah, Umi. 2011. Pengantar Keterampilan Berbicara Berbasis Cooperative Learning Think Pair Share. Yogyakarta: Media Perkasa

Madyawati, Lilis. 2016. Strategi Pengembangan Bahasa Pada Anak. Jakarta: Prenada Media Group.

Mudini dan Purba, Salamat. 2009. Pembelajaran Berbicara. Jakarta: Depdiknas.

Tarigan, Henry Guntur. 2008. Berbicara Sebagai Suatu Keterampilan Berbahasa. Bandung: Angkasa. 